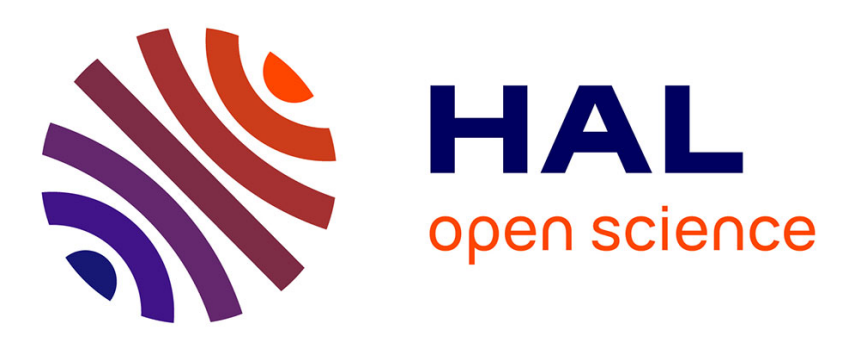

\title{
Mucorolactone, a Macrolactone from Mucor sp. SNB-VECD13A, a Fungus Isolated from the Cuticle of a Vespidae Species
}

Seindé Touré, Morgane Barthélemy, Jonathan Sorres, Grégory Genta-Jouve, Isabelle Dusfour, Véronique Eparvier, Didier Stien

\section{To cite this version:}

Seindé Touré, Morgane Barthélemy, Jonathan Sorres, Grégory Genta-Jouve, Isabelle Dusfour, et al.. Mucorolactone, a Macrolactone from Mucor sp. SNB-VECD13A, a Fungus Isolated from the Cuticle of a Vespidae Species. Organic Letters, 2018, 20 (13), pp.3780-3783. 10.1021/acs.orglett.8b01367 . hal-02333761

\section{HAL Id: hal-02333761 \\ https://hal.science/hal-02333761}

Submitted on 25 Oct 2019

HAL is a multi-disciplinary open access archive for the deposit and dissemination of scientific research documents, whether they are published or not. The documents may come from teaching and research institutions in France or abroad, or from public or private research centers.
L'archive ouverte pluridisciplinaire HAL, est destinée au dépôt et à la diffusion de documents scientifiques de niveau recherche, publiés ou non, émanant des établissements d'enseignement et de recherche français ou étrangers, des laboratoires publics ou privés. 


\title{
Mucorolactone, a Macrolactone from Mucor sp. SNB-VECD13A, a Fungus Isolated from the Cuticle of a Vespidae Species
}

\author{
Seindé Touré, ${ }^{\dagger}$ Morgane Barthélémy, ${ }_{*}^{\dagger}{ }^{\dagger}$ Jonathan Sorres, ${ }^{\dagger}$ Grégory Genta-Jouve, ${ }^{\ddagger}$ Isabelle Dusfour, \\ Véronique Eparvier, ${ }^{* \dagger}$ Didier Stien, ${ }^{*},+$ \\ ${ }^{\dagger}$ CNRS, Institut de Chimie des Substances Naturelles (ICSN), UPR2301, Université Paris-Sud, 1 avenue de la terrasse, \\ 91198 Gif-sur-Yvette, France \\ * C-TAC, UMR 8638 CNRS, Faculté de Pharmacie de Paris, Université Paris Descartes, Sorbonne Paris Cité, 4 Avenue de \\ l'Observatoire, 75006 Paris, France \\ ${ }^{\S}$ Institut Pasteur de la Guyane (IPG), Unité de Contrôle et Adaptation des Vecteurs, 97306 Cayenne, Guyane française \\ ${ }^{\perp}$ Sorbonne Université, CNRS, Laboratoire de Biodiversité et Biotechnologie Microbienne, USR3579, Observatoire \\ Océanologique, 66650 Banyuls-sur-mer, France
}

Supporting Information Placeholder

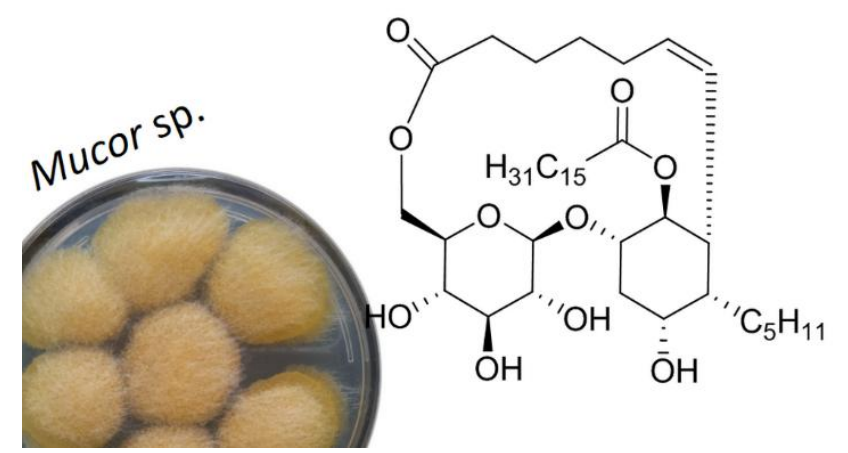
ABSTRACT: The newly discovered macrolactone mucorolactone, along with 8 known compounds, was isolated from an ethyl acetate extract of the insect-born fungus Mucor sp. All structures were elucidated using 1D and 2D NMR and MS spectroscopic experiments. Relative and absolute configurations of the original skeleton of mucorolactone was deduced from NOESY experi- ment, from the ${ }^{13} \mathrm{C}$ NMR chemical shifts calculation based on the DP4 probability method, and from the comparison of experi- mental and calculated electronic circular dichroism spectra.

Natural products are a historically successful option in the drug discovery and development process. They have an indispensable role to play, continuing to provide for and influence the search and development of current therapeutic drugs in spite of the reduced level of natural products based drug discovery programs. ${ }^{1}$ The recent decade has seen a growing recognition that natural products isolated from plants and animals may sometimes be the metabolic products of co-living microbes. ${ }^{2}$ This fact leads researchers to the exploration of underrated ecological niches to identify novel chemical entities. Consequently, natural products regulating insect-microbe interactions have emerged as a promising resource for drug discovery. ${ }^{3,4}$ These microorganisms, either mutualists or pathogens, generate a number of secondary metabolites involved in the mechanisms of defense, protection, or virulence. ${ }^{5,6}$ Among them, entomopathogenic microorganisms are expected to produce insecticides and antimicrobial compounds during the process of infection and proliferation. ${ }^{7}$ In our work, we undertook the exploration of secondary metabolites of the fungus Mucor sp. isolated from the cuticle of an alive, yet infected, unidentified wasp (Vespidae) collected in French Guiana.

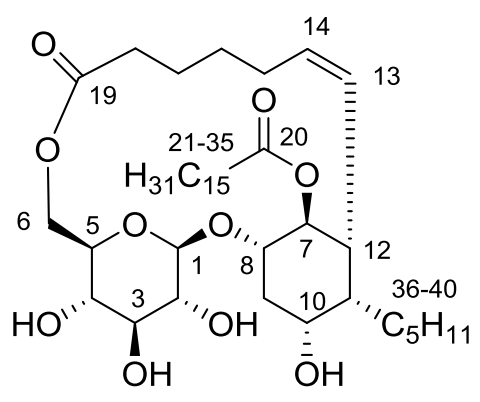

Figure 1. The structure of mucorolactone (1).

A fractionation was performed on the ethyl acetate extract of Mucor sp. SNB-VECD13A and a new compound 1 (Figure 1) was isolated, along with known dehydroabietic acid, ${ }^{8}$ cyclo(L-Pro-L-Phe) ${ }^{9} \mathrm{~N}$-acetyltryptophane, ${ }^{10}$ daidzein, ${ }^{11}$ 2-(4hydroxyphenyl)ethyl acetate, ${ }^{12}$ phenylacetic acid, ${ }^{13}$ ergosterol- 
$5 \alpha, 8 \alpha$-peroxide, ${ }^{14}$ and ergosta-5,7,22-trienol. ${ }^{15}$ Known compounds were identified by the comparison of their analytical data with those from the literature, as described in the Supporting Information.

Table 1. ${ }^{1} \mathrm{H}$ and ${ }^{13} \mathrm{C}$ NMR Data of Compound $1^{\mathrm{a}}$

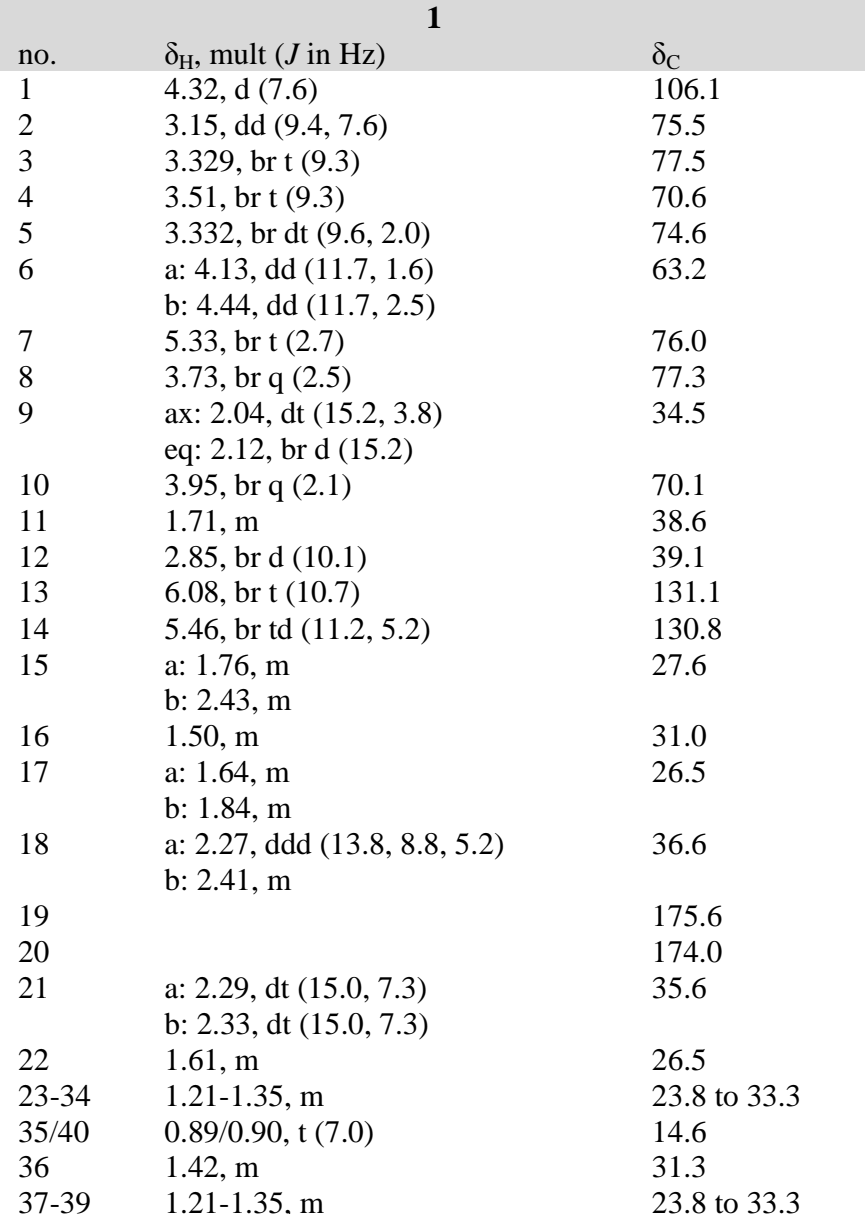

${ }^{\text {a }}$ Measured at $500 \mathrm{MHz}$ for ${ }^{1} \mathrm{H}$ and $125 \mathrm{MHz}$ for ${ }^{13} \mathrm{C}$, in methanol$d_{4}$

Compound 1 was obtained as a yellow oil. It has the molecular formula $\mathrm{C}_{40} \mathrm{H}_{70} \mathrm{O}_{10}$, as deduced from the HR-ESI ${ }^{+}$-MS molecular ion sodium adduct at $\mathrm{m} / z$ 733.4881 $[\mathrm{M}+\mathrm{Na}]^{+}$ (calcd for $\mathrm{C}_{40} \mathrm{H}_{70} \mathrm{O}_{10} \mathrm{Na}, 733.4879$ ), corresponding to 6 degrees of unsaturation. The examination of the ${ }^{1} \mathrm{H},{ }^{13} \mathrm{C}$, and HSQC spectra of $\mathbf{1}$ allowed the identification of two triplet methyls at $\delta_{\mathrm{H}} 0.89$ and 0.90 and thirteen methines $\left[\delta_{\mathrm{H}} 6.08,5.46,5.33\right.$, $4.44,4.32,4.13,3.95,3.73,3.51,3.34,3.33,3.15$ and 2.85] among which two were olefinic protons $\left(\delta_{\mathrm{H}} 6.08, \mathrm{H}-13\right.$ and $\delta_{\mathrm{H}}$ 5.46, H-14). Several methylenes were identified under a broad signal at $\delta_{\mathrm{H}}$ 1.30. The ${ }^{13} \mathrm{C}$ NMR spectrum of $\mathbf{1}$ showed the presence of two quaternary carbons corresponding to ester groups at $\delta_{\mathrm{C}} 175.7$ and 174.0 and nine oxygenated carbons between $\delta_{\mathrm{C}} 63.1$ and 106.1 (Table 1). The presence of a pyranose moiety was confirmed by the sequence of ${ }^{1} \mathrm{H}-{ }^{1} \mathrm{H}$ COSY cross-peaks for $\mathrm{H}-1 / \mathrm{H}-2 / \mathrm{H}-3 / \mathrm{H}-4 / \mathrm{H}-5$ and $\mathrm{H}-6$ along with $\mathrm{HMBC}$ correlation $\mathrm{H}-1$ to $\mathrm{C}-5$ (Figure 2). An additional sequence of ${ }^{1} \mathrm{H}-{ }^{1} \mathrm{H}$ cross-peak $\mathrm{H}-7 / \mathrm{H}-8 / \mathrm{H}-9 / \mathrm{H}-10$ and $\mathrm{H}-11$ along with HMBC correlations between H-8/C-9, H-10/C-8 and $\mathrm{C}-12, \mathrm{H}-11 / \mathrm{C}-12$, and $\mathrm{H}-12 / \mathrm{C}-7$ and $\mathrm{C}-10$ allowed the determination of another six-membered ring linked to the pyranose moiety by $\mathrm{C}-8$ as shown by the $\mathrm{H}-1 / \mathrm{C}-8$ and $\mathrm{H}-8 / \mathrm{C}-1$ correlations (Figure 2). Note that the unusual C-11-C-12 bond is revealed by the $\mathrm{H}-11-\mathrm{H}-12$ COSY correlation, and the correlations $\mathrm{H}-11 / \mathrm{C}-12, \mathrm{H}-10 / \mathrm{C}-12$ and $\mathrm{H}-12 / \mathrm{C}-10$ in HMBC.

The ${ }^{1} \mathrm{H}-{ }^{1} \mathrm{H}$ COSY sequence signal from $\mathrm{H}-12$ to $\mathrm{H}-18$ established a carbon side chain linked to $\mathrm{C}-12$ and includes the two methines $\mathrm{H}-13$ and $\mathrm{H}-14$ in a cis double bond $(J=11.3 \mathrm{~Hz}$, Figure 2). HMBC cross signals H-6/C-19 and H-18/C-19 confirmed the C-6-O-C-19 linkage demonstrating the presence of a macrolactone. The correlation of $\mathrm{H}-7$ with $\mathrm{C}-20$ and ${ }^{1} \mathrm{H}-{ }^{1} \mathrm{H}$ coupling between $\mathrm{H}-11$ and $\mathrm{H}-36$ allowed us to attach an alkyl side chain in $\mathrm{C}-11$ and a fatty acid chain in $\mathrm{C}-7$. The relative length of both side chains could not be established by NMR due to extensive overlapping of the $\mathrm{CH}_{2}$ signals in ${ }^{1} \mathrm{H}$ and ${ }^{13} \mathrm{C}$. In LC-ESI-MS ${ }^{2}$, the fragmentation of the pseudomolecular ion yielded two characteristic fragments at $\mathrm{m} / \mathrm{z}$ $255.2323\left(\left[\mathrm{C}_{16} \mathrm{H}_{31} \mathrm{O}_{2}\right]^{-}\right)$and $471.2584\left(\left[\mathrm{M}-\mathrm{C}_{16} \mathrm{H}_{31} \mathrm{O}\right]^{-}\right)$. These originate from the cleavage of the $\mathrm{C}-7-\mathrm{O}$ and the $\mathrm{O}-\mathrm{C}-20$ bonds, respectively (Scheme 1). In $\mathrm{LC}_{-} \mathrm{ESI}^{+}-\mathrm{MS}^{2}$, the $[\mathrm{M}+\mathrm{Na}]^{+}$adduct fragmented to give a daughter ion at $\mathrm{m} / \mathrm{z}$ $477.2457\left(\left[\mathrm{M}+\mathrm{Na}-\mathrm{C}_{16} \mathrm{H}_{32} \mathrm{O}_{2}\right]^{+}\right)$. All these findings are consistent with the existence of palmitate esters on $\mathrm{C}-7$ and a fivecarbon side chain in $\mathrm{C}-11$.

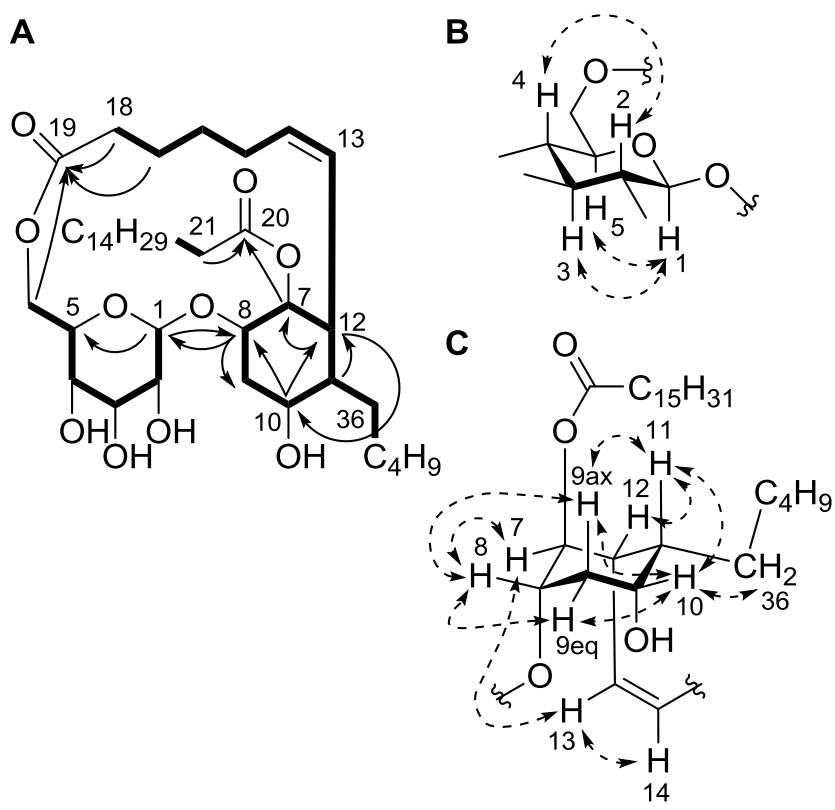

Figure 2. A) COSY (bold), and key HMBC (plain arrows) correlations in compound 1 ; B) key NOE correlations in the glucose moiety (dashed arrows). Hydroxyl groups in positions 2-4 have not been represented for clarity; C) key NOE correlations in the cyclohexane ring (dashed arrows).

The anomeric proton configuration was assigned based on $\mathrm{H}-1$ chemical shift and on the coupling constant value of 7.6 $\mathrm{Hz}$ between $\mathrm{H}-1$ and $\mathrm{H}-2$. This is consistent with a $\beta-$ configuration. Based on the same principle, the vicinal coupling constant between the successive pyranose protons provided information about their relative configuration. Large $J$ couplings observed within the sequence $\mathrm{H}-2$ to $\mathrm{H}-5$ confirmed the axial configuration of $\mathrm{H}-2, \mathrm{H}-3, \mathrm{H}-4$ and $\mathrm{H}-5$. These orientations were confirmed by the NOESY spectrum where correlations were observed between the anomeric proton $\mathrm{H}-1\left(\delta_{\mathrm{H}}\right.$ 4.32) and $\mathrm{H}-3$ and/or $\mathrm{H}-5$, and between $\mathrm{H}-2$ and $\mathrm{H}-4$. The 
pyranose was therefore defined as a glucose moiety. The relative stereochemistry in the cyclohexane ring was determined as follows. First, $\mathrm{H}-8$ and $\mathrm{H}-10$ both have 3 small vicinal coupling constants $(J \approx 2.5 \mathrm{~Hz}$ and $J \approx 2.1 \mathrm{~Hz}$, respectively). Since one of the H-9 protons is necessarily axial, then $\mathrm{H}-8$ and $\mathrm{H}-10$ must be equatorial. The axial $\mathrm{H}-9$ proton at $\delta 2.04$ could be identified due to the NOE correlation with $\mathrm{H}-11$. H-12 has one large coupling with $\mathrm{H}-13$ and two small couplings with $\mathrm{H}$ 11 and H-7. Since H-11 is axial, then $\mathrm{H}-12$ has to be equatorial. This was confirmed by the NOE correlation between H-11 and H-12. Finally, the COSY experiment indicated that H-7 was coupled with H-9eq (W-coupling) and should therefore be equatorial. This assumption was reinforced by the NOE coupling between $\mathrm{H}-7$ and $\mathrm{H}-13$.

Scheme 1. LC-MS ${ }^{2}$ Fragmentation of 1 (up: positive mode; down: negative mode)
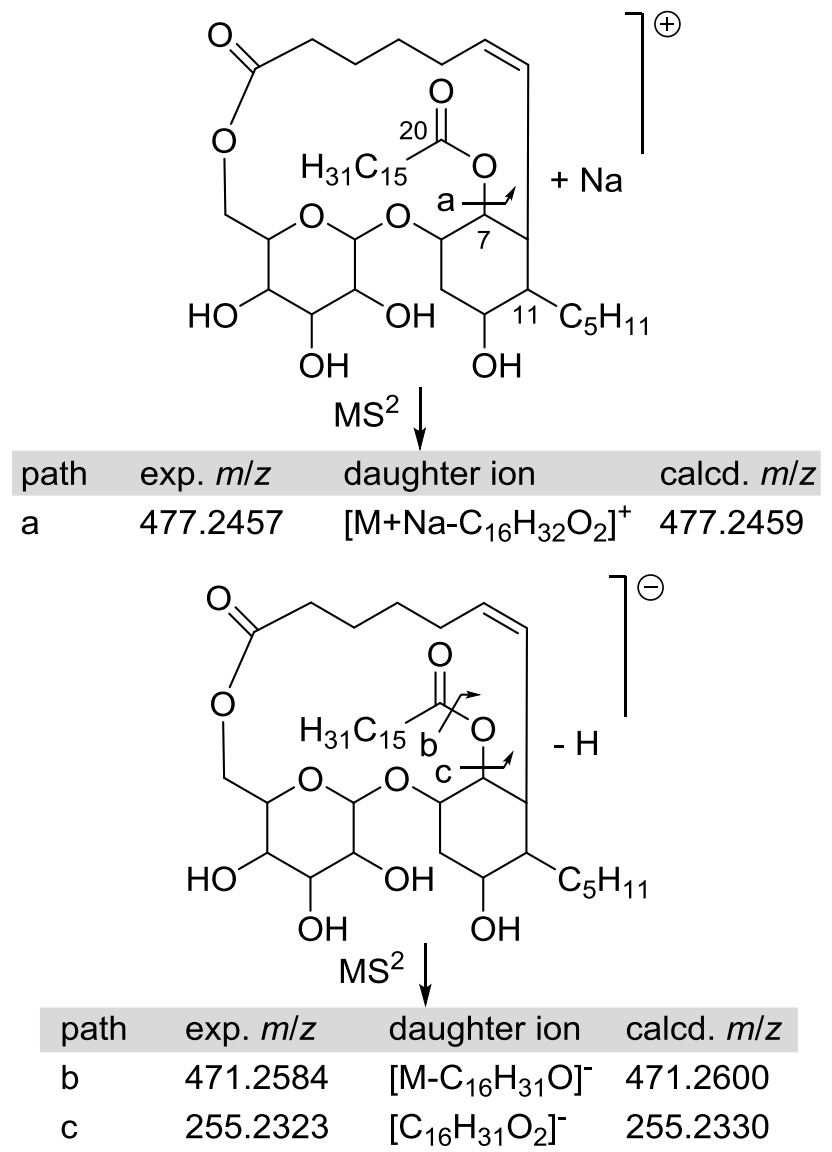

The only stereochemical information linking the glucose to the cyclohexane ring is an NOE correlation between $\mathrm{H}-1$ and $\mathrm{H}-8$. However, this was not enough to determine the relative configurations of these two moieties (Figure 3). A ${ }^{13} \mathrm{C} N M R$ chemical shift calculation by the DP4 probability method was performed. ${ }^{16}$ Due to the flexibility of the compound, ${ }^{13} \mathrm{C}$ NMR calculations have been performed on the conformers within $1 \mathrm{kcal} . \mathrm{mol}^{-1}$ using Gaussian 09W with the B3LYP method at the $6-311+\mathrm{G}(\mathrm{d}, \mathrm{p})$ level. The Boltzmann weighted chemical shifts have been compared to the experimental ones using an in house implementation of the Java source code available on the Goodman's group page (http://www-
jmg.ch.cam.ac.uk/tools/nmr/DP4/). The diastereoisomer a was deduced to be correct with a $100 \%$ probability.

The experimental electronic circular dichroism spectrum of 1 was recorded in $t$-BuOMe. It shows a broad positive absorption band centered at $220 \mathrm{~nm}$. The calculated ECD spectrum of the enantiomer in Figure 1 agreed well with the experimental data (See supporting information), therefore supporting the absolute configuration in which the glucose moiety is D. The initial goal was to find new insecticides. Mucorolactone was tested on Aedes aegypti larvae and was not active.

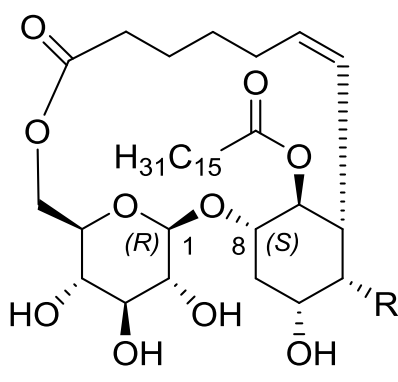

a

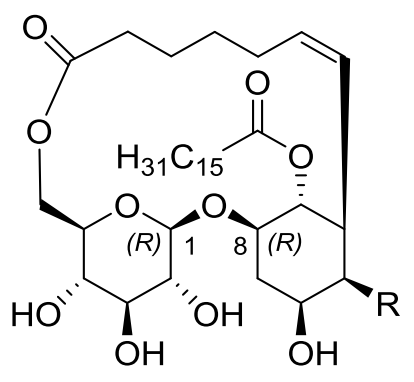

b
Figure 3. Both possible diastereoisomers of $\mathbf{1}(\mathrm{R}=$ pentyl).

In conclusion, this letter reports the first description of mucorolactone (1), a unique macrocyclic compound isolated from a fungus of the genus Mucor. Interestingly, the right side of compound $\mathbf{1}$, from the ester group in C-19 to the pentyl side chain (C-36-C-40), seems to be formed by cyclization (formation of the C-11-C-12 bond) and oxidation of $\gamma$-linolenic acid to generate the functionalized cyclohexane ring. Bacteria from the Alicyclobacillus and Sulfobacillus genera are known to produce $\omega$-cyclohexyl fatty acids, ${ }^{17}$ but simple 6-membered rings in the middle of a fatty acid chain are very rare in nature. One example is the isolation of rubrenoic acids $\mathrm{A}-\mathrm{C}$ from the marine bacterium Alteromonas rubra. ${ }^{18}$ These compounds probably originate from the 7-12 cyclization of a C16 fatty acid, but the biosynthetic pathway leading to the formation of such compounds is not known. It will be interesting to further investigate the biosynthesis of mucorolactone, which can be obtained in large amounts from Mucor sp. SNB-VECD13A.

\section{ASSOCIATED CONTENT}

\section{Supporting Information}

The Supporting Information is available free of charge on the ACS Publications website.

Detailed experimental procedures, NMR and MS data (PDF)

\section{AUTHOR INFORMATION}

\section{Corresponding Author}

*Tel: +33 1698236 79. E-mail: veronique.eparvier@cnrs.fr *Tel: +33 4301924 76. E- mail: didier.stien@cnrs.fr

\section{Author Contributions}

$\|$ These authors contributed equally.

\section{ACKNOWLEDGMENT}

This work benefitted from an "Investissement d'Avenir" grant managed by the Agence Nationale de la Recherche (CEBA, ref 
ANR-10-LABX-25-01). The authors are very grateful to C. Gourmel (BioSavane association) and C. Duplais (CNRS) for collecting the infected insect. The authors also acknowledge Marcelino Suzuki (Sorbonne Université) and Mehdi Beniddir (Université Paris Sud) for constructive discussions.

\section{REFERENCES}

(1) Newman, D. J.; Cragg, G. M. J. Nat. Prod. 2016, 79, 629-661.

(2) Crawford, J. M.; Clardy, J. Chem. Commun. 2011, 47, 75597566.

(3) Challinor, V. L.; Bode, H. B. Ann. N. Y. Acad. Sci. 2015, 1354, 82-97.

(4) Traxler, M. F.; Kolter, R. Nat. Prod. Rep. 2015, 32, 956-970.

(5) Kaltenpoth, M. Trends Microbiol. 2009, 17, 529-535.

(6) Bode, H. B. Angew. Chem., Int. Ed. 2009, 48, 6394-6396.

(7) Scholte, E. J.; Knols, B.G.; Samson, R. A.; Takken, W. J. Insect Sci. 2004, 4, 1-24.

(8) Touré, S.; Dusfour, I.; Stien, D.; Eparvier, V. Tetrahedron Lett. 2017, 58, 3727-3729.

(9) Ding, L.; Yuan, W.; Sun, H.; Xu S. Chem. Nat. Compd. 2016, 52, 969-970.

(10) Jin, Y.-S.; Jing-Ling, Du, J.-L.; Yang, Y.; Jin, L.; Song, Y.; Zhang, W.; Chen, H.-S. Chem. Nat. Compd. 2011, 47, 257-260.

(11) Liu, B.; Kongstad, K. T.; Qinglei, S.; Nyberg, N. T.; Jäger, A. K.; Staerk, D. J. Nat. Prod. 2015, 78, 294-300.

(12) Pfaff, D.; Nemecek, G.; Podlech, J. Beilstein J. Org. Chem. 2013, 9, 1572-1577.

(13) Malineni, J.; Keul, H.; Möller, M. Dalton Trans. 2015, 44, 17409-17414.

(14) Wu, Q.-P.; Xie, Y.-Z.; Deng, Z.; Li, X.-M.; Yang, W.; Jiao, C.-W.; Fang, L.; Li, S.-Z.; Pan, H.-H.; Yee, A. J.; Lee, D. Y.; Li, C.; Zhang, Z. Guo, J.; Yang, B. B. PloS One 2012, 7, e44579.

(15) Zhao, J.; Mou, Y.; Shan, T.; Li, Y.; Zhou, L.; Wang, M.; Wang, J. Molecules 2010, 15, 7961-7970.

(16) Smith, S. G.; Goodman, J. M. J. Am. Chem. Soc. 2010, 132, 12946-12959.

(17) Ciuffreda, E.; Bevilacqua, A.; Sinigaglia, M.; Corbo, M. R. Microorganisms 2015, 3, 625-640.

(18) Holland, G. S.; Jamieson, D. D.; Reichelt, J. R.; Viset, G.; Wells, R. J. Chem. Ind. (London) 1984, 850. 